\title{
TORRENS AND CUSTOMARY LAND TENURE: A CASE STUDY OF THE LAND TitLEs RegistRATION ACT 2008 OF SAMOA
}

\section{Ruiping Ye*}

This article describes the customary land tenure in Samoa, and analyses the effects of the introduction of a Torrens system of land registration on the customary land tenure. In particular, it examines the registration of adjudicated customary land (customary land in respect of which judgment has been made by the Land and Titles Court) under the Land Titles Registration Act 2008, as well as the combined effect of the Taking of Land Act 1964 and Torrens registration on customary land. It argues that the LTRA 2008 may be repugnant to the Constitution and that the Torrens system is incompatible with customary land tenure. It recommends that the law expressly exclude customary land from the indefeasibility of title effect of the Torrens system.

\section{INTRODUCTION}

Like most of the South Pacific island countries, Samoa ${ }^{1}$ retains a land tenure system which is predominantly customary. Ways to increase economic growth in Samoa through improving land administration have long been sought; a change to the land registration system is one of them.

The Land Titles Registration Act of Samoa was passed in 2008 and came into force in March 2009. The Act adopts the Torrens registration of title system and requires the registration of public land, freehold land and customary land leases and licences. It also allows the registration of customary land in respect of which judgment has been made by the Land and Titles Court. ${ }^{2}$ The

* LLB (Xiamen), LLM ( $V U W)$, Barrister and Solicitor of the High Court of New Zealand. Submitted as part of the LLM programme at Victoria University of Wellington. Recepient of the 2009 Quentin-Baxter Public/International Law Prize. I would like to thank Professor Tony Angelo and Professor Richard Boast for their invaluable advice and support.

1 Samoa is the independent Pacific island state formerly known as "Western Samoa". A part of the Samoan archipelago is known as "American Samoa". This article is not concerned with American Samoa.

2 Land Titles Registration Act 2008, s 9(1) and (2) [LTRA 2008]. By Torrens system it means a registration of title system which was first established by Sir Robert Torrens in Australia in 1858. For an example of a 
Land Titles Registration Act 2008 (the LTRA 2008) was described as "controversial"3 and has caused a wide outcry from the Samoan community, fearing that they would lose their customary land. ${ }^{4}$

This article analyses the interaction of the LTRA 2008 and the existing system of land tenure in Samoa, with a focus on the impact of the LTRA 2008 on customary land. Part II provides a necessary backdrop about Samoa and its legal system, as well as an overview of Samoan land tenure, land registration before the commencement of the LTRA 2008, and the LTRA 2008. Part III canvasses customary land tenure in Samoa and the operation of the Land and Titles Court. Part IV discusses the debate about the relationship between registration of customary land and economic growth, and examines Samoa's experience in registration of customary land before the LTRA 2008.

Part V analyses the registration of customary land in respect of which judgment has been made by the Land and Titles Court (adjudicated customary land) under the LTRA 2008. It interprets the relevant provisions in the LTRA 2008 and their effect on customary land tenure. It argues that the provisions in the LTRA 2008 are either ambiguous or inconsistent with the substantive law on customary land tenure, and the ambiguity, inconsistency and loopholes in the Act will potentially cause the conversion of customary land into freehold land and render aspects of the LTRA 2008 repugnant to the Constitution of the Independent State of Samoa (the Constitution). It further argues that Torrens registration of customary land is unnecessary, unworkable, and incompatible with the customary land tenure in Samoa. This part also recommends that a systematic recording system should replace the sporadic registration system of customary land, and the LTRA 2008 should be amended to expressly exclude the application of indefeasibility of title to customary land.

Part VI analyses the implication of Torrens registration in light of the Taking of Land Act 1964. It discusses the law and the practice of taking of land in Samoa, and argues that the full implementation of a Torrens system could facilitate large scale land loss and land conversion in Samoa. This article concludes that while the legislature of Samoa recognises the importance of customary land tenure to its society, it has not appreciated the nature and effect of the Torrens system. It is of the essence of any Torrens system that it is not merely a system of registration but that it changes substantive property law in various significant ways. Samoa should adapt the system to suit its traditional, societal and legal reality. More specifically, this article recommends that Samoa should take a holistic approach in its land reform, and amend the substantive law and the

representative Torrens-type system, see G W Hinde, D W McMorland and Katherine C Buchanan Hinde McMorland \& Sim Land Law in New Zealand (LexisNexis, Wellington, 2004), in particular, ch 8.

3 Iati Iati "Controversial Land Legislation in Samoa: It's not just about the land" <www.globalfocus.org.nz> (All website sources in this article were correct at 20 March 2010).

4 For example, see Savea Sano Malifa "To all Samoans Worldwide - You are in Danger of Losing your Family Land" (15 February 2009) Samoa Observer; Maua Faleauto "Land Titles Registration, Constitution" (4 February 2009) Samoa Observer<www.samoaobserver.ws>. 
LTRA 2008 to suit its overarching principles and objectives, to ensure consistency among the statutes, and to clarify the whole registration scheme.

\section{SAMOA AND ITS LAND TENURE}

\section{A Samoa and its Legal System}

Samoan society and land tenure were traditionally governed by Samoan custom, under the leadership of the chiefs (matai). Following the first European visit to the archipelago by the French in 1768 , treaties were signed between the Chiefs and European nations in 1838-1839. 5 In the second half of the 19th century, Samoa was engaged in chaotic tribal wars while western powers competed with each other in Samoa. The Treaty of Berlin in 1889 between the United States of America, the United Kingdom and Germany restored the self-governance of Samoa. Ten years later in 1899 these three powers reached another agreement which divided the archipelago into Western Samoa and American Samoa. Western Samoa was a German Territory from 1899 until 1914 when it became occupied by a New Zealand expeditionary force. It was administered by New Zealand from 1919, first under a League of Nations mandate, and after World War II as a United Nations Trust Territory. On 1 January 1962, Western Samoa became an independent sovereign state. The Constitution was amended to rename Western Samoa as Samoa in 1997.

All German law was repealed in 1920 by New Zealand's administration. ${ }^{6}$ Upon independence, Samoa gained full legislative power as well as retaining the existing law from pre-independence. ${ }^{7}$ The law currently in force in Samoa includes the Constitution, Acts of the Samoan Parliament and subsidiary legislation, English Common law and equity, ${ }^{8}$ customary law, ${ }^{9}$ as well as the preindependence law which includes the Ordinances made by the New Zealand Administrator or assented to by the New Zealand High Commissioner, and Acts of New Zealand which were enacted for or specifically applied to Samoa. ${ }^{10}$ Worth noting is that the courts in Samoa have interpreted "English common law" as "a body of law originally exported from England", and have "continued to demonstrate affinity with New Zealand" courts' decisions. ${ }^{11}$ By contrast, most of the New Zealand

5 Unless otherwise specified, the information contained in this section is taken from the Government of Samoa website $<$ www.govt.ws $>$.

6 See Guy Powles "Western Samoa" (1993) Asia-Pac Const YB 306 at 310 ["Western Samoa"].

7 The Constitution of the Independent State of Samoa [the Constitution], art 114.

8 The Constitution, art 111(1).

9 The Constitution, art $111(1)$.

10 The Constitution, arts 111(1) and 114. Also see Don Paterson "Sources of Law in the South Pacific Samoa" <www.paclii.org $>$.

11 Powles "Western Samoa", above n 6, at 311. 
statutes were repealed by the Reprint of Statutes Act 1972; the Property Law Act 1952 is one of the few survivors. ${ }^{12}$

The Samoan government includes a Head of State, the executive branch, the Parliament, and the Judiciary. ${ }^{13}$ The Judiciary consists of the Supreme Court and the Court of Appeal which are superior courts of record, and subordinate Magistrate's Courts. ${ }^{14}$ The Constitution also provides for a Land and Titles Court to be set up, which has "such jurisdiction in relation to Matai titles and customary land as may be provided by [an Act of Parliament]". 15

Samoa consists of the two large islands of Savaii and Upolu, the small islands of Manono and Apolima and several uninhabited islets. The whole country is divided into 11 traditional districts, which are tracts of land running from the mountains to the sea, and 330 villages, each of which consists of several extended families. ${ }^{16}$ Traditionally each family is headed by a matai, each village is governed by the village fono, and each district is governed by the district council. However, the formal structure of government "makes no direct provision for the government of municipalities or districts". ${ }^{17}$ The Village Fono Act 1990 recognises some traditional powers of the village fono.

The total land area is 284,898 hectares, about 70 percent of which is suitable for agriculture or cattle grazing, ${ }^{18}$ but a big proportion of it is subject to moderate to severe limitations for this purpose. ${ }^{19}$ Consequently, only under half of the 70 percent is in agricultural and residential use. ${ }^{20}$

By 2001 Samoa had a total population of 176,848 . Samoans make up 92.6 per cent of the population; Euronesians (persons of European and Polynesian blood) comprise 7 per cent and Europeans 0.4 per cent.

12 Ibid, at 310.

13 See the Constitution generally.

14 The Constitution, Part VI. Also see Powles 'Western Samoa", above n 6, at 328.

15 The Constitution, art 103. The operation of Land and Titles Court will be discussed later in this article.

16 See Making Land Work (Australian Agency for International Development, Canberra, 2008) Vol 1 at 113 [Making Land Work].

17 Powles 'Western Samoa", above n 6, at 323

18 See Ben Acquaye and Ron Crocombe (eds) Land Tenure and Rural Productivity in the Pacific Islands (University of the South Pacific, Suva, 1984) at 150 [Land Tenure and Rural Productivity].

19 Land Equity International Customary Land Tenure Review, Samoa Second Infrastructure and Asset Management Project Component 5.01: Land Administration and Survey, Technical Assistance Report No 25 (Prepared for the Ministry of Natural Resources, Environment and Meteorology, January 2006) at 12 [Customary Land Tenure Review].

20 Acquaye and Crocombe Land Tenure and Rural Productivity, above n 18, at 150. The situation might have changed in the past 20 years, although statistics are not readily available. 


\section{B Samoa Land Tenure and its Land Law}

There are three types of lands in Samoa: customary land, freehold land and public land. ${ }^{21}$ These three types of land each corresponds respectively to Native land, European Land and Crown land under the New Zealand administration. ${ }^{22}$

Customary lands are lands that are held "in accordance with Samoan custom and usage and with the law relating to Samoan custom and usage". ${ }^{23}$ The meaning of "Samoan custom and usage" does not require holding from time immemorial or universal acceptance: it means the customs and usages of Samoa "accepted as being in force at the relevant time" and includes both those that are accepted by the people of Samoa in general and those that are "accepted as being in force in respect of a particular place or matter". ${ }^{24}$ However, there appears to be a general pattern of customary land holding, as will be demonstrated later in this article. Customary land is mainly governed by the Constitution, the Alienation of Customary Land Act 1965, the Land and Titles Act 1981, and Samoan customs and usage.

Freehold land was previously called "European land", which meant "land held from the Crown for an estate in fee-simple". ${ }^{25}$ Although "fee simple" is a creation of the feudal system and Samoa never had a European-style feudal system, s 268 of the Samoa Act 1921, using the words "land held from the Crown" in the definitions of the three types of land, indicated that New Zealand had asserted that all lands were vested in the Crown. Freehold titles were mostly acquired by the Europeans before the alienation of customary land was prohibited in 1889 by the Treaty of Berlin. ${ }^{26}$ The current definition of freehold land is "land held from Samoa for an estate in fee simple". ${ }^{27}$ Freehold land is mainly governed by the Alienation of Freehold Land Act 1972 and the LTRA 2008.

Public land means "land vested in Samoa that is free from customary title and from any estate in fee simple". ${ }^{28}$ Public land was previously called Crown land, which means "land vested in the Crown free from Native title and from any estate in fee simple". ${ }^{29}$ This is also equivalent to Crown

21 The Constitution, art 101.

22 See the classification and definitions of the categories of land in the Samoa Act 1921 (NZ), s 268 (repealed).

23 The Constitution, art 101(2).

24 Land and Titles Act 1981, s 2.

25 Samoa Act 1921 (NZ), s 268(3) (repealed).

26 See the Final Act of the Conference on the Affairs of Samoa (Treaty of Berlin 1889), art IV s 1. Also see the discussion in Sia'aga v OF Nelson Properties Ltd [2008] WSCA 14; CA 04/08 (19 September 2008) para 9 (CA).

27 The Constitution, art 101(3).

28 The Constitution, art 101(4).

29 Samoa Act 1921 (NZ), s 268(2) (repealed). 
Land in New Zealand. There are a few statutes which relate to public land, such as the Water Act 1965, the Forests Act 1967 and the National Parks and Reserves Act 1974. For the purpose of this article, the relevant statute is the Taking of Land Act 1964.

There are other statutes, such as the Property Law Act 1952, the Land Titles Investigation Act 1966, the Lands, Surveys and Environment Act 1989 and the Land for Foreign Purposes Act 1992/1993, which apply to land in different ways.

Customary land tenure has remained relatively static in the past few decades. It was recorded that 81 per cent of the land was customary land at the time of independence, ${ }^{30}$ and it remained the same in a 2002 record. ${ }^{31}$ The percentages of freehold land and public land vary in different sources, ranging from freehold land 4 per cent and public land 15 per cent ${ }^{32}$ to freehold land 12 per cent and public land 7 per cent. ${ }^{33}$ Although it is not clear whether the difference is due to different times of recording, the change was still relatively small.

\section{Land Registration and the Land Titles Registration Act 2008}

Samoa has had a land registration system since the time of New Zealand administration. ${ }^{34}$ The Samoa Land Registration Order 1920 (NZ) (the 1920 Order) required the registration of Crown land, European land and any European interest in Native land. ${ }^{35}$

The Land Registration Act 1992/1993 (the LRA 1992/1993) replaced the 1920 Order and its subsequent amendment Orders. ${ }^{36}$ The LRA 1992/1993 required registration of public land, freehold land, and upon application, customary land leases. ${ }^{37}$ It retained the principles and method of registration of the 1920 Order. In fact, Part IV (Registration) of the LTA 1992/1993 corresponded to the 1920 Order and its Amendment Order 1921, with most of the language remaining unchanged.

30 Making Land Work, above n 16, Vol 1 at 118.

31 See Jennifer Corrin "Resolving Land Disputes in Samoa" in Making Land Work, above n 16, Vol 2, 199 at 203 ["Resolving Land Disputes in Samoa"].

32 Ibid.

33 Chris Grant "Accessing Land for Public Purposes in Samoa" in Making Land Work, above n 16, Vol 2, 265 at 269 ["Accessing Land for Public Purposes"]. This source does not indicate the year of statistics.

34 It is noted that Samoa also had land registration under German administration, but the German period is not examined in this article.

35 Samoa Land Registration Order 1920 (NZ), cl 7 (repealed).

36 Land Registration Act 1992/1993 (repealed), s 43 [LRA 1992/1993].

37 Ibid, s 15. 
Although the registration system prior to the LTRA 2008 was recognised as registration of deeds, ${ }^{38}$ both the 1920 Order and the LTA 1992/1992 were dissimilar to the Deeds Registration Act 1908 of New Zealand. A more accurate description of the Samoa registration system is that it is "a hybrid system which is an amalgam of old deeds registration principles with more modern title registration practices". 39

The registration of deeds system is the "maintenance of a public register in which documents affecting interests in land are copied or abstracted". ${ }^{40}$ Registration is based on the transaction, and it is the instrument that gets registered. The registration of deeds determines the priority of deeds by reference to the date of their registration, but does not affect the legal force of any deed. ${ }^{41} \mathrm{~A}$ registered deed "does not in itself prove title" ${ }^{42}$ positively. By contrast, registration of title, commonly known as the Torrens system, ${ }^{43}$ is "an authoritative record ... of the rights to clearly defined units of land as vested for the time being in some particular person or body". ${ }^{44}$ The registration is based on the parcel of land, and it is the rights and interests that are registered against that land. The register or certificate of title is the conclusive evidence of title and the state "accepts responsibility for the validity of transactions". 45

In Samoa's case, on the one hand, under the 1920 Order, the Land Register is "a register ... of the legal title to all Crown land, European land, and European interests in Native land". ${ }^{46}$ The LTA 1992/1993 continued "the same Land Register as that existing under the same name immediately prior to the commencement" of the Act. ${ }^{47}$ These provisions suggested that the registration was based on parcels of land and the titles to land were registered. On the other hand, the 1920 Order

38 For example, see Office of the Attorney General of Samoa Legislative Drafting Update (Volume 1, Issue 2, 2008) "Land Titles Registration Act 2008" [Office of Attorney General].

39 Land Equity International Final Report Draft Samoa Second Infrastructure and Asset Management Project Component 5.01: Land Administration and Survey, Technical Assistant Report No 33 (Prepared for the Ministry of Natural Resources, Environment and Meteorology, February 2006) at 20.

40 S Rowton Simpson Land Law and Registration (Cambridge University Press, Cambridge, 1978) at 14 [Simpson].

41 Ibid.

42 Ibid.

43 There are many variations of registration of title system, and the Torrens system is only one of them. See Simpson, above $n$ 40, chs 3-5. For the purpose of this article, we need not distinguish among them and can equate the registration of title system with the Torrens system.

44 Simpson, above $\mathrm{n} 40$, at 15-16.

45 Ibid, at 16.

46 Samoa Land Registration Order 1920, cl 6 (repealed).

47 LRA 1992/1993, s 14. 
mentioned that that "[n]o instrument of title shall in any manner affect the legal title to land in Samoa until and unless such instrument is registered in the Land Register". ${ }^{48}$ This provision accorded with Simpson's description that in a deeds registration system, "a statute may provide that deeds may not be received or admitted in court as evidence of title". ${ }^{49}$ The LTA 1992/1993 replicated this provision. ${ }^{50}$ There was no mention of registration as conclusive evidence of title or state-guaranteed title. It is in this sense that some called the registration system a "de facto registration of title", ${ }^{1}$ which registered title but the registration was not conclusive evidence of title, and ultimately differed from the Torrens system. Others define it as registration of title, which is the method of registration, but not title by registration, which is the legal effect of the Torrens system. ${ }^{52}$

The LTRA 2008 replaced the LRA 1992/1993. ${ }^{53}$ The most apparent and fundamental change is the adoption of the Torrens system. One of the purposes of the LTRA 2008 is to establish "ownership of interest in land by registration"; 54 the folio is conclusive evidence of title; 55 and the estate of the registered proprietor is paramount. ${ }^{56}$ Also entailed in Torrens indefeasibility is compensation by the government to persons who suffer loss or damage as a result of the operation of the Act, ${ }^{57}$ in contrast to the LRA 1992/1993 which specified that the Government was not liable for any loss or damage caused by the act, omission or default of the Registrar or the Registrar's subordinates. ${ }^{58}$

There are two mechanisms to bring lands under the registration system. The first one is by the conversion of the previous register to the new register. Upon the commencement of the LTRA 2008, all lands registered in the Land Register under the LRA 1992/1993 are deemed to be registered under the LTRA 20008 as qualified title land..$^{59}$

48 Samoa Land Registration Order 1920, cl 8.

49 Simpson, above $\mathrm{n} 40$, at 14 .

50 See the LRA 1992/1993, ss 16 and 17.

51 Land Equity International Project Inception Report Samoa Second Infrastructure and Asset Management Project Component 5.01: Land Administration and Survey Technical Assistance Report No 1 (March 2005) at 18 [Project Inception Report].

52 See, for example, Vaosa v Attorney-General [2000] WSSC 23 (4 August 2000) (SC).

53 LTRA 2008, s 94.

54 Ibid, preamble.

55 Ibid, s 12.

56 Ibid, s 32.

57 Ibid, Part 13.

58 LRA 1992/1993, s 38.

59 The LTRA 2008, s 14. 
The second mechanism is the registration of new transactions after the commencement of the LTRA 2008. Section 9(1) of the LTRA 2008 states that the Registrar must register any land that "becomes public land, freehold land, or customary land leased or licensed under the provisions of the Alienation of the Customary Land Act 1965" after the commencement of the Act. Section 9(2) states that the Registrar may also register "customary land in respect of which judgment has been made by the Land and Titles Court", for which the Land and Titles Act 1981 requires registration. Compared to the LRA 1992/1993, the LTRA 2008 makes the registration of customary land leases and licences compulsory, and expressly includes the registration of adjudicated customary land. The government emphasises that the LTRA 2008 "continues present law allowing the registration of customary land [where leases or judgments are concerned]". ${ }^{60}$ However, the LTRA 2008 as a whole has far reaching effects on land tenure, especially customary land tenure, as will be demonstrated below.

\section{SAMOAN CUSTOMARY LAND TENURE}

\section{A Custom and Customary Land Tenure}

Traditionally Samoan society is organised into villages, "each with its own clearly demarcated territory" and its own "fono, or governing council of chiefs", ${ }^{61}$ which used to function "as executive, [legislature] and judiciary". ${ }^{62}$ Each village is composed of a number of aiga (extended family). ${ }^{63}$ Aiga "as the basic descent group, constitutes the means by which all Samoans relate to their ancestors, their matai ... their land and their descendants". ${ }^{64}$ It was said that the aiga was the centre of social life, and the village was the centre of political life. ${ }^{65}$

The main elements of the family heritage are land and titles. ${ }^{66}$ Each aiga has a title, or name, which is handed down from generation to generation. ${ }^{67}$ The relative ranks of the chiefly titles of

60 Office of the Attorney General, above n 38.

61 Derek Freeman Margaret Mead and Samoa: The making and unmaking of an anthropological myth (Australian National University Press, Canberra, 1983) at 121 [Samoa: an anthropological myth].

62 Powles "Western Samoa", above n 6, at 308.

63 Freeman Samoa: an anthropological myth, above n 61, at 121.

64 Powles "Western Samoa", above n 6, at 308.

65 E Schultz "The Most Important Principles of Samoan Family Law, and the Laws of Inheritance" (1911) 20(2) Journal of the Polynesian Society 43 at 45 [Schultz].

66 Ron Crocombe and Malama Meleisea (eds) Land Issues in the Pacific (University of Canterbury, Christchurch; University of the South Pacific, Suva, 1994) at 169 [Land Issues]. Also see Ron Crocombe (ed) Land Tenure in the Pacific (3 ed, USP, Suva, 1987) at 75 [Land Tenure], where the author states that the aiga own the land and matai titles.

67 Schultz, above n 65, at 43. 
different aiga "are laid down in strict hierarchical order."68 The titles are held by the matai (chief), who is the head of the family, and the "administrator and trustee of [the family] heritage". ${ }^{69}$ On the one hand, the pule (authority) of the matai title is vested in the aiga potopoto, ${ }^{70}$ which means that the aiga potopoto determines who should be the matai and hold the title and administer the land for the family. ${ }^{71}$ On the other hand, the members of the family must serve the matai and obey his authority, while the matai must look after the family's welfare.

Aiga also own the family land, but the pule over the land is vested in the matai. Any heir of the aiga is entitled to own and use family land, but the entitlement is only realised on the rendering of service to the matai and on continuing residency on family land. ${ }^{72}$ The matai may allocate lands for family members to build a house on, to plant and to harvest. Depending on the closeness of kinship and the service to the matai, the rights to occupy and use the land are different among the members of the family. ${ }^{73}$ These interests are called tautua interest. Compared with the tradition of working on the same plot of land and cooking on the same stove, there is an increasing trend, which has been described as "individual entrepreneurship", ${ }^{74}$ where the matai grants "constrained individual land use rights" of a certain plot of land to the family members, and the family members in return provide the matai with a proportion of the produce, or provide services or goods when required..$^{75}$

It has been observed that matai may subdivide the expanding family into sub-branches and appoint subsidiary matai. ${ }^{76}$ The principal matai has overriding pule over the land, the subsidiary matai has pule over the land, and the aiga have ownership of the land. ${ }^{77}$ This description does not accord with earlier authority, but it is not clear whether it is due to inaccurate expression or because the custom has moved on. According to a former Land and Titles Court president, the matai or aiga

68 Freeman Samoa: an anthropological myth, above n 61, at 121.

69 Crocombe and Meleisea Land Issues, above n 66, at 169.

70 The aiga potopoto comprises all members of the family including all relations. See CC Marsack "Land and Titles Court of Western Samoa - Notes on the Practice of the Court and the Principles Adopted in the Hearing of Cases" (1961) at 6 [Marsack].

71 Ibid.

72 Crocombe and Meleisea Land Issues, above n 66, at 170. Also see Crocombe Land Tenure, above n 66, at 79 .

73 Acquaye and Crocombe Land Tenure and Rural Productivity, above n 18, at 140.

74 Ibid, 122. Also see J Tim O'Meara "From Corporate to Individual Land Tenure in Western Samoa" in R Gerard Ward and Elizabeth Kingdon (eds) Land, Custom and Practice in the South Pacific (Cambridge University Press, Cambridge, 1995) [O'Meara] generally.

75 Acquaye and Crocombe Land Tenure and Rural Productivity, above n 18, at 140.

76 Crocombe and Meleisea Land Issues, above n 66, at 169.

77 Ibid, at 170. 
could not create new titles, although on occasion a title could be split and held by two or more people. ${ }^{78}$ In this case, the matais will hold one title jointly and have joint pule over land. ${ }^{79}$ The Land and Titles Court has "frown[ed] upon" this situation. ${ }^{80}$ By the 1970s, the proliferation of matai titles was out of control, due to the fact that only matai had the right to vote. ${ }^{81}$ The Western Samoa Committee on Matai Titles, Customary Land and the Land and Titles Court in 1975 ("the Review Committee") emphasised that "it was most unusual for a new title to be created", ${ }^{82}$ and recommended "legislative action to control the appointment of matai". ${ }^{83}$

When a matai dies or relinquishes the position, the pule over land does not go to the heir of his body, but to the successor of the title. However, access to the title itself is "gained primarily by descent from a previous title holder" ${ }^{84}$ who may or may not be living with the family prior to the succession.

As indicated earlier in this article, the majority of land in Samoa is customary land. Apart from those lands that are clearly identified to be customary land, s 8 of the Land and Titles Act 1981 ("LTA 1981") also specifies that any Samoan freehold land ${ }^{85}$ in respect of which there has been a recital or declaration that such land be held in accordance with the customs and usages of the Samoan people, or any land ordered by the Land and Titles Court to be customary land, is deemed to be customary land. ${ }^{86}$ The Land Titles Amendment Act 2008 adds that "any land conveyed by Government or any public body by way of deed which provides that the land shall be held in accordance with the customs and usages of the Samoan people" is deemed to be customary land. ${ }^{87}$

78 Marsack, above n 70, at 8 .

79 Ibid, at 9

80 Ibid.

81 Samoa introduced universal suffrage in the Electoral Amendment 1990, s 5. Before this only Matai Title holders could vote, see the Electoral Act 1963, s 16.

82 Western Samoa Committee on Matai Titles, Customary Land and the Land and Titles Court Report on Matai Titles, Customary Land and the Land and Titles Court (December 1975) at 19 [the Review Committee Report].

83 Ibid, at 22.

84 Crocombe Land Tenure, above n 66, at 78 .

85 Section 8 of the Land and Titles Act 1981 [LTA 1981] refers to s 13 of the Samoan Land and Titles Protection Ordinance 1934 for the definition of "Samoa freehold land", which basically means land held in fee simple by Samoans. The Samoan Land and Titles Protection Ordinance 1934 was repealed by s 95 of the LTA 1981, and the category of Samoa freehold land has disappeared. These lands are now either freehold land or customary land. See the Constitution, art 101.

86 LTA 1981, s 8.

87 Land Titles Amendment Act 2008, s 2. 
Most customary land belongs to extended families. The unallocated bush lands in the village belong to the whole village, from which the villagers take their resources. The villages also have communal land for public affairs, such as schools and sports. ${ }^{88}$ In addition, some villages also administer areas of public land under management arrangements. ${ }^{89}$ Over time it could become unclear whether these lands are public land or customary land. ${ }^{90}$ At the district level there are also areas of reserve land to which everyone in the district has access. ${ }^{91}$

\section{B Alienation of Customary Land}

In 1889, following the land rush in the late 19th century, the United States, Great Britain and Germany signed the Treaty of Berlin, which forbade the alienation of customary land to Europeans. ${ }^{92}$ The New Zealand administration continued the protection of customary land ownership. ${ }^{93}$ Currently, although most of the Pacific island states prohibit alienation of customary land by statutes, Samoa does so in an entrenched Constitution. ${ }^{94}$ Article 102 of the Constitution prohibits the alienation or disposition of customary land or of any interest in customary land. This includes prohibition of sale and mortgage of customary land or interests in it, and prohibition of land or interests in it "being taken in execution or be assets for the payment of the debts of any person on his decease or insolvency". ${ }^{95}$ This constitutional limitation is obviously highly relevant to any attempt to restructure Samoan land tenure by statute.

The Constitution permits the granting of a lease or licence of customary land or taking of customary land for public purposes, under the authorisation of an Act of Parliament. ${ }^{96}$ Accordingly, the Taking of Land Act 1964 and the Alienation of Customary Land Act 1965 provide for such lease, licence and taking of land. Other than these, the prohibition of alienation is absolute, which

88 Peter Larmour, Ron Crocombe and Anna Taungenga (eds) Land, People and Government: Public lands policy in the South Pacific (University of South Pacific, 1981) at 48 [Land, People and Government].

89 The Review Committee Report, above n 82, at 64.

90 Ibid, at 65 .

91 Larmour, Crocombe and Taungenga Land, People and Government, above n 88, at 48.

92 Treaty of Berlin, art IV s 1. Also see the discussion in Customary Land Tenure Review, above n 19, at 4.

93 For example, see the Samoan Land and Titles Protection Ordinance 1934 (repealed). It appears that the alienation of customary land was not forbidden, but was controlled through the requirement of an authorisation by the High Commissioner. See clause 3 of the Ordinance.

See Making Land Work, above n 16, Vol 1 at 39.

95 The Constitution, art 102.

96 Ibid. 
means that customary land cannot be alienated to members of the family or other clans, and cannot be exchanged between customary land owners. ${ }^{97}$

Although the inalienability of customary land might restrict foreign investment, it has been generally recognised that the leasing and licensing of customary land was an effective way to use customary land for modern economic development. ${ }^{98}$ It has also been accepted that the constitutional mandate of inalienability of customary land cannot be breached unless article 102 is amended. However, while the amendment of the Constitution requires over two-thirds vote in support in the Parliament, by virtue of article 109 of the Constitution, any amendment to article 102 in addition requires the support of over two-thirds of the valid vote in a public referendum. ${ }^{99}$ Article 109 itself is entrenched in the same way. ${ }^{100}$ Given Samoans' strong attachment to their land, it is virtually impossible to amend article 102 .

\section{Investigation of Land and Ownership}

Samoan land titles are determined by the Commission set up under the Land Titles Investigation Act 1966, and the Land and Titles Court. The Land Titles Investigation Commission investigates and determines "individual ownership of or property in any land in Samoa" upon claims by any person. ${ }^{101}$ If the Commission determines the land is freehold land in law or in equity, or is public land in law but the claimant has an estate or interest in equity, it will grant the estate or interest accordingly. ${ }^{102}$ However, the Commission has no authority to make any determination or order if it finds that land in issue is customary land. ${ }^{103}$ Instead, the Land and Titles Court decides disputes among Samoans in respect of customary land.

The Land and Titles Court is the successor of the Land and Titles Commission, which was set up by the German administration. ${ }^{104}$ The Constitution confirms the continuing operation of the Land and Titles Court, and grants it "jurisdiction in relation to matai titles and customary land as may be provided by [an Act of Parliament]". ${ }^{105}$ The LTA 1981 provides that the Land and Titles

97 Although it is suggested that exchange between customary land owners should be allowed, and may in fact be happening. See Customary Land Tenure Review, above n 19, at 24.

98 See Making Land Work, above n 16, Vol 1 at 38; Customary Land Tenure Review, above n 19, at 33.

99 The Constitution, art 109.

100 Ibid.

101 Land Titles Investigation Act 1966, s 15.

102 Ibid, s 18. The terms "freehold land in law or in equity" and "estate or interest ... in equity" are used in s 18 , but these terms are not defined.

103 Ibid, s 20 .

104 Crocombe and Meleisea Land Issues, above n 66, at 171-172.

105 The Constitution, art 103. 
Court has jurisdiction in all matters relating to Samoan names and titles, and in all claims and disputes between Samoans relating to customary land. ${ }^{106}$ The jurisdiction may be exercised "on the petition of any person claiming a bona fide interest, or on the petition of the Registrar". ${ }^{107}$ The Court must apply Samoan custom and usage, the law relating to Samoan custom and usage and any enactment expressed to apply to the Court in exercising its jurisdiction. ${ }^{108}$ The Land and Titles Court is a court of record. ${ }^{109}$

The Land and Titles Court is different from the ordinary courts in many aspects. First, in the Constitution, the Land and Titles Court is not mentioned under the part dealing with the Judiciary, but under the part on Land and Titles. Secondly, the constitution and jurisdiction of Supreme Court and Court of Appeal are provided for in detail in the Constitution, ${ }^{110}$ but the constitution and jurisdiction of the Land and Titles Court are provided for in an ordinary statute, the LTA 1981. Judges and assessors of the Court need not be legal professionals, but are matais with "character, ability, standing and reputation". ${ }^{111}$ Thirdly, although the practice and procedure of the Court are determined by the rules of the Supreme Court, ${ }^{112}$ the LTC does not seem to apply the Evidence Act $^{113}$ and the Court proceeding is usually inquisitorial. ${ }^{114}$ Legal practitioners have no right of audience in the Land and Titles Court. ${ }^{15}$ Fourthly, any appeal against a decision of the Court is to the Land and Title Court itself. The appeal is heard by the President and two Samoan Judges and is by way of rehearing. ${ }^{116}$ There is no right of further appeal ${ }^{117}$ and the decisions or orders of the Court are not subject to judicial review. ${ }^{118}$ Finally, the Court's final decision must be published in

106 LTA 1981, s 34. Section 14A of the Taking of Land Act 1964 grants it specific jurisdiction in deciding which matai has pule over the land to be taken, and the Alienation of Customary Land Act 1965 grants the Land and Titles Court specific jurisdiction to hear objections against leasing or licensing of customary land.

107 LTA 1981, s 37.

108 Ibid.

109 Ibid, s 25.

110 See the Constitution, Part VI.

111 LTA 1981, s 28.

112 LTA 1981, s 47.

113 Corrin "Resolving Land Disputes in Samoa", above n 31, at 203.

114 Ibid, at 207.

115 LTA 1981, s 92.

116 Ibid, ss 77 and 88 .

117 Ibid, s 90.

118 Ibid, s 71. It seems that at least before 1993 the Supreme Court was of the view that this is an effective ouster clause; see Powles "Western Samoa", above n 6, 329. However, the Supreme Court has changed its opinion since then. For example, the Court of Appeal case Peniamina v Land and Titles Court [2004] 
the Savali (the national newspaper) and every decision is "deemed to be judgment in rem and shall bind all Samoans who are affected by it, whether parties to the proceedings or not". 119

The Review Committee described the Land and Titles Court as the "people's court", which had "the responsibility of deciding cases ... which inevitably have far reaching political and social consequences". ${ }^{120}$ It recommended that the Land and Titles Court be given "fitting recognition" by the Constitution as it did with the Supreme Court and the Court of Appeal, as opposed to providing it in an ordinary Act which implied the "inferior constitutional status" of the Court. ${ }^{121}$ The Constitution remains unchanged in this regard.

\section{REGISTRATION OF CUSTOMARY LAND}

\section{A The Debate about Registration of Customary Land}

Whether the privatisation and registration of customary land could improve land productivity has been a matter of debate for many decades. Some commentators view traditional land tenure as a constraint on the development of Pacific island countries. ${ }^{122}$ In the 1970 s substantive reform of customary land tenure facilitated by registration of title was proposed. ${ }^{123}$ Papua New Guinea (PNG) was among the first to adopt registration of title. ${ }^{124}$ However, the registration process was very slow. It was observed that in PNG no parcel of land was registered between 1950s and 1960s since the introduction of Torrens system in the 1950s, ${ }^{125}$ and "little was achieved" in the effort of registering customary land since then. ${ }^{126}$ The registered land, which was less than 3 per cent of the

WSCA 1 (17 December 2004) was a judicial review case. Also see Corrin "Resolving Land Disputes in Samoa", above n 31, at 208 and Customary Land Tenure Review, above n 19, at 19.

119 LTA $1981, \mathrm{~s} 70$

120 The Review Committee Report, above n 82, at 95.

121 Ibid, at $95-96$

122 See, for example, the discussion in Crocombe Land Tenure, above $\mathrm{n} 66$, at 76

123 See Simpson, above $\mathrm{n} 40$, at ch 12 .

124 Kenya was an example of adopting the Torrens system in Africa. Kenya has encountered same problems in that the people were reluctant to register their customary land, and registration has caused high volume of disputes. See Simon Coldham "The Effect of Registration of Title upon Customary land Rights in Kenya" (1978) 22 JAfrL 91.

125 Making Land Work, above n 16, Vol 1 at 35.

126 Acquaye and Crocombe Land Tenure and Rural Productivity, above n 18, at 34. 
land area in $\mathrm{PNG}^{127}$ was almost all for foreigners, and has caused many disputes and social injustices. ${ }^{128}$

The relationship between land tenure, registration and economic growth in the Pacific Islands has also long been the subject of research. ${ }^{129}$ Some commentators observe that security of tenure can increase productivity while others envisage that security of tenure may inhibit productivity in the developing countries. ${ }^{130}$ Many Pacific countries have adopted the Torrens system in one way or another. ${ }^{131}$ Statistics show that registration of title increases productivity in some countries, and reduces productivity in others. ${ }^{132}$ The rationale for increasing productivity is that registration gives security of title, which is an incentive for land owners to invest and work on their land. ${ }^{133}$ The reasons for the decline of productivity are more complicated. It may be that inter-tribal disputes are reduced, but intra-tribal disputes increase. ${ }^{134}$ It may be that the registration procedure leaves room for corruption. ${ }^{135}$ It may be that registration causes fragmentation of land holding, as population grows. ${ }^{136}$ In any case, it seems that the introduction of Torrens has one of two effects: either customary lands are privatised, or the locals resist registration of customary land which results in only lands held by foreigners being registered. ${ }^{137}$

More recently, the debate about the relationship between customary land tenure and economic development has become heated between different camps. Some commentators argue that customary land tenure is a barrier to development everywhere. They assert that "no country in the world has developed without individual property rights", and promote registration of private

127 Ibid.

128 See Dr John Mugambwa "Transportation of the Torrens System to Developing Countries: Uganda and Papua New Guinea" in David Grinlinton (ed) Torrens in the Twenty-first Century (LexisNexis, Wellington, 2003)115 at 122-131. About the general discussions on land reform and registration, see Nancy Sullivan (ed) Culture and Progress: The Melanesian philosophy of land and development in Papua New Guinea (Divine World University Press, Madang, 2002).

129 See Acquaye and Crocombe Land Tenure and Rural Productivity, above n 18, generally.

130 Ibid, at 27.

131 Ibid, at ch 3 .

132 Ibid, at 28.

133 See Simpson, above n 40, at 228.

134 For an example, see the discussion about Fiji in Acquaye and Crocombe Land Tenure and Rural Productivity, above n 18, at 32.

135 Ibid, at 30, discussion on Tonga.

136 Ibid, at 28-29, discussion on Cook Islands.

137 See the overview of land registration in the island nations in Acquaye and Crocombe Land Tenure and Rural Productivity, above n 18, at ch 3. 
property rights in land in the Pacific. ${ }^{138}$ Others employ substantial evidence to demonstrate that this is not the case and vigorously defend customary tenures. ${ }^{139}$ They argue that the flexibility of customary tenure allows the society to "adjust to the changing demands ... under modern circumstances", 140 and seek ways that can increase tenure security without "destroying the social fabric underlying customary land tenures". ${ }^{141}$ International agencies such as the World Bank, the Asia Development Bank and the Australia Agency for International Development have initiated research in this area, and called for reform of land tenure in the developing countries. ${ }^{142}$

In summary, the relationship between customary land tenure and economic growth is still under debate, and the positive effect of Torrens registration of customary land on economic development is far from definite.

\section{B Registration of Customary Land in Samoa}

Customary land traditionally was not subject to registration in Samoa. Similar to the debate in the wider scene, some commentators argued that customary land tenure is a constraint on Samoa's development and urged change of tenure and introduction of a Torrens registration system; ${ }^{143}$ others found that most development problems "are more administrative, cultural and economic than they are inherently tenure difficulties". ${ }^{144}$ They argued that the customary land tenure system provides "life-time security for all members of the family whether they live and work on the land or not", ${ }^{145}$ and it is "fundamental to Samoan society". ${ }^{146}$ The Review Committee, while noting the attack on

138 See Helen Hughes "The Pacific is Viable!" in The Centre for Independent Studies Issue Analysis (No 53, December 2004) <www.cis.org.au>.

139 See, for example, Jim Fingleton (ed) Privatising Land in the Pacific: A Defence of Customary Tenures (The Australia Institute, Discussion Paper No. 80, 2005) <www.tai.org.au> (last accessed 21 June 2009) [Fingleton Defence of Customary Tenures]. Also see Tim Anderson "Valuation and Registration of Customary Land in Papua New Guinea" (2006, IASCP Conference, Bali, June 2006) <www.iascp.org>.

140 Fingleton Defence of Customary Tenures, above n 139, at 34

141 Ibid, at 5.

142 For example, see the World Bank "Traditional Land Tenure and Land Use Systems in the Design of Agricultural Projects" (World Bank Staff Working Papers No 561, Washington, 1983) and "Reforming Urban Land Policies and Institutions in Developing Countries" (Urban Management Program, Washington, 1992).

143 See the discussion in Acquaye and Crocombe Land Tenure and Rural Productivity, above n 18, at 137.

144 Crocombe and Meleisea Land Issues, above n 66, at 179. Also see Acquaye and Crocombe Land Tenure and Rural Productivity, above n 18, at 147-152.

145 Acquaye and Crocombe Land Tenure and Rural Productivity, above n 18, at 121.

146 Ibid. 
customary land tenure, opined that "[t]he economy of the country depends as much on the social stability of the traditional systems as it does on agricultural production". ${ }^{147}$

In the 1970s, the then Department of Lands and Survey proposed to systematically and comprehensively survey and register customary land. ${ }^{148}$ The Review Committee recognised the need to register and crystallise the Land and Titles Court's decisions, especially the registration of boundaries and pule over land. ${ }^{149}$ This was necessary as over the years, the incidence of litigation about customary land has been high; ${ }^{150}$ over 85 per cent of the disputes were over pule over land and boundaries. ${ }^{151}$ The high incidence of land litigation was said to indicate uncertainty over land tenure. ${ }^{152}$ The Review Committee envisaged that registration of customary land could gradually build up land data, but it disagreed with the comprehensive approach. It recommended a more gradual process, because systematic survey and registration of the land would produce more litigation, would be costly, and were not applicable to circumstances of Samoa. ${ }^{153}$ The process was to register lands that had gone through the Land and Titles Court proceeding. The Register would be kept by the Justice Department. The recommended method of registration was based on the parcel of land, but it would not register title to land. Instead, it would register pule over land and tautua interests. ${ }^{154}$

When the LTA 1981 was finally enacted, the Committee's recommendation was simplified in three short sections. Sections 11 requires that the Land and Titles Court's judgments, orders and declarations concerning the title or status of any customary land or interest in such land be transmitted to the Land Registrar. Section 12 specifies the Land Registrar's duty to register every judgment so transmitted, and to enter in the Land Register a memorial showing that the land or interest concerned is a customary land or interest. Section 13 states that registration of trust instruments in respect of customary land is not unlawful, notwithstanding that the then in force Samoa Land Registration Order 1920 prohibited the registration of trust instruments.

These provisions are substantially different from the recommendation of the Committee. First, they do not indicate how adjudicated customary land should be registered, apart from the provision

147 The Review Committee Report, above n 82, at 70-71.

148 Ibid, at 76.

149 Ibid, at 76-77.

150 Corrin "Resolving Land Disputes in Samoa", above n 31, at 210: "Samoans are increasingly adept at bringing and fighting claims before the Land and Titles Court".

151 Crocombe and Meleisea Land Issues, above n 66, at 173.

152 Simpson, above n 40, at 230.

153 The Review Committee Report, above n 82, at 76.

154 Ibid, at 79-81. 
that the Land Registrar should "register every judgment, order or declaration received". ${ }^{155}$ This seems to indicate that it is the registration of instrument as opposed to the Review Committee's recommendation of crystallising the boundaries and pule over a piece of land. Secondly, the tautua interest is not recognised in the Register, instead at best it would be registered as contained in a trust instrument. A tautua interest is different from a trust interest, in that it is an absolute right to use and occupy, but subject only to a matai's pule. The use of common law terms here changes the customary land concepts, ${ }^{156}$ and arguably jeopardises the untitled persons' interests.

The later statutes on land registration also fail to clarify the registration mechanism. Instead, they add confusion to it, as will be explained below.

The LRA 1992/1993 did not expressly include adjudicated customary land in the registration, but $\mathrm{s} 18$ mentioned application for registration of Orders of the Land and Titles Court. It stated that applications "shall be made by depositing with the Registrar a copy thereof" and "such copy shall be retained by the Registrar as an official record". This section created a potential inconsistency of law. Under the LTA 1981 the registration is compulsory and through official transmission. Under the LRA 1992/1993, the registration is through application by individuals, which arguably is optional. The section itself specified the Registrar's duty to retain a copy of judgment, but added nothing to the registration method. Since registration has never been done, ${ }^{157}$ it is not clear whether the two Acts provide for two different registration systems. The LTRA 2008 presents more problems than the LRA 1992/1993, but this is an issue for the next section.

Under a credit from the International Development Association, ${ }^{158}$ Samoa launched the Infrastructure Asset Management Programme (IAMP) in 1999. The purpose of the IAMP was to "enhance the economic, environmental and social sustainability of transport and coastal infrastructure assets". ${ }^{159}$ The first phase of the IAMP was completed in 2004. The second phase, which was completed in June 2008, had a component on Land Administration and Survey. This component focused on better administration of leases and licences of customary land, but seemed

155 LTA 1981, s 12(1).

156 For how the use of common law terms in legislation and the operation of the common law in the courts have changed customary law concepts, see Jennifer Corrin "Customary Land and the Language of the Common Law" (2008) 37 Comm L World Rev 305. Also see J S Fingleton "Legal Recognition of Indigenous Groups" (FAO Legal Papers Online, December 1998) at $33<$ www.fao.org $>$.

157 Corrin "Resolving Land Disputes in Samoa", above n 31, at 212; Customary Land Tenure Review, above n 19 , at 20 .

158 The International Development Association is part of the World Bank.

159 The information on the Infrastructure Asset Management Project comes from the Ministry of Natural Resources and Environment "Second Infrastructure Asset Management Project" <www.mnre.gov.ws>. 
not to directly challenge the fundamental inalienability of customary land tenure. ${ }^{160}$ Therefore, whether customary land should be privatised is not an issue in Samoa. Nevertheless, a review of customary land tenure was undertaken, ${ }^{161}$ and initially the registration of customary land generally was within contemplation. ${ }^{162}$ The wider community reacted very strongly against the proposition of registering customary land, ${ }^{163}$ and the Customary Land Tenure Adviser vigorously defended customary land tenure. ${ }^{164}$ In the end, the government reportedly amended the Land Titles Registration Bill before its third reading, ${ }^{165}$ to reassure the community that the introduction of the Torrens system would not affect customary land holding.

\section{REGISTRATION OF ADJUDICATED CUSTOMARY LAND}

\section{A The Registration System and Process}

The LTRA 2008 does not provide a new registration mechanism for adjudicated customary land other than the vague provision of s 63. Section 63 states that registration of the Land and Titles Court orders, as well as other public documents, "shall be made by depositing with the Registrar a copy thereof ... and such copy shall be retained and registered by the Registrar as an official record". This provision is a word for word repetition of s 18 of the LRA 1992/1993. ${ }^{166}$ The fundamental shift to Torrens system as a general rule and the lack of clear provision raise three questions: first, whether the Torrens registration applies to adjudicated customary land; second, whether the registered customary land remains customary land or becomes freehold land; third, under whose name the land would be registered.

160 See the Asia Development Bank Samoa: Promoting Economic Use of Customary Land Phase (Technical Assistance Consultant's report, February 2009) <www.pid.adb.org>.

161 The result of the review is the Customary Land Tenure Review, above n 19.

162 See Land Equity International Project Inception Report, above n 51, at 21; Customary Land Tenure Review, above $\mathrm{n} 19$, at 41 .

163 See examples given in Part I of this article.

164 See Customary Land Tenure Review, above n 19, generally.

165 It was reported that the government amended the Bill to exclude registration of customary land, see Maggie Tait "Customary Land Excluded from Samoa Bill" New Zealand Herald (12 May 2008) $<$ www.nzherald.co.nz> (last accessed 4 August 2009). However, the amendment was actually to add subss (4) and (5) to s 9, which emphasise that the LTRA 2008 does not change the non-alienability of customary land as stipulated by the Constitution. See the Land Titles Registration Bill $2005<$ www.mnre.gov.ws $>$ (last accessed 18 September 2009), cf the LTRA 2008. Arguably the insertion of subss (4) and (5) has not added any meaning to the Act, since on the one hand, in any case an ordinary legislation should not violate the entrenched Constitution; on the other hand, it is not for an ordinary legislation to declare whether it violates the Constitution or not.

166 Apart from adding "and registered" after "retained". 


\section{Whether Torrens applies to adjudicated customary land}

Section 9(2) of the LTRA 2008 specifies that "the Registrar may also include in the Register" adjudicated customary land. Section 93 of the Act specifies that "[n]othing in this Act shall be deemed to repeal or modify the provisions of any of sections 11, 12 or 13" of the LTA 1981. These provisions are open to two different interpretations. The first interpretation is that the registration system of adjudicated customary land remains unchanged; the second is that while retaining the LTA 1981 registration, the LTRA 2008 also allows Torrens registration of adjudicated customary land as a parallel system.

The wording of s 63 - "such copy shall be retained and registered" - suggests that the instrument itself shall be registered. However, the use of "as an official record", as opposed to "Register" and "folio" which are used throughout the Act, indicates that this section is about the record of the judgments, and is quite separate from the registration scheme itself. The Act is called the "Land Titles Registration" Act, and it is to provide for "the establishment and maintenance of a Register of title to land". ${ }^{167}$ The inclusion of adjudicated customary land in the overall scheme of registration, without express language to the contrary, indicates the Torrens system applies to adjudicated customary land. Section 93 simply preserves the recording system required in the LTA 1981, but does not exclude the application of the Torrens system to adjudicated customary land. More fundamentally, the LTA 1981 does not specify the effect of registration, and thus the operation of the Torrens system will not "repeal or modify" any provision of the LTA 1981. Finally, s 9(2) of the LTRA 2008 uses the term "may also include in the register" adjudicated customary land, which indicates that the Torrens system may apply side by side with the compulsory registration under the LTA 1981.

As indicated above, the language of s 63 of the LTRA 2008 is almost identical to that of s 18 of the LRA 1992/1993. However, since the LTRA 2008 expressly allows the registration of adjudicated customary land, as opposed to the LRA 1992/1993 which was silent about this matter, and since the overall scheme and effect of registration are changed, arguably s 63 of the LTRA 2008 has different implications from s 18 of the LRA 1992/1993. It seems that the LTRA 2008 provides a system of registration parallel to the LTA 1981: registration of the judgments is compulsory, but registration of title on the authority of the judgments is optional.

The parallel registration is not without precedent: New Zealand Maori Land Court's judgments are recorded in the Maori Land Court, and the ownership of the lands as the judgments determine is registered with Land Information New Zealand. ${ }^{168}$ The differences are that in New Zealand the two

167 LTRA 2008, preamble.

168 See discussion in New Zealand Law Commission Review of the Land Transfer Act 1952 (NZLC IP10, Wellington, 2008) at ch 10 [NZLC LTA 1952 Review]. Also see Richard P Boast "The Implications of Indefeasibility for Maori Land" in Torrens in the Twenty-first Century, above n 128, 101 at 102-103 ["The Implications of Indefeasibility for Maori Land"]. 
registrations are done by different institutions as opposed to Samoa's which are both done by the Land Registrar, and that New Zealand has a substantive law which stipulates converting customary land to freehold land through the Maori Land Court's investigation while Samoa's substantive law holds on to the customary land tenure.

\section{Whether registered customary land is customary land or freehold land}

Section 9 subsections (4) and (5) of the LTRA 2008 emphasise that the Act does not change the inalienability of customary land as stipulated by the Constitution, and does not change ownership of or affect interest in customary land. One may argue that even if the registration of adjudicated customary land is registration of title, it could still be registered as customary land. If it is registered as customary land, arguably indefeasibility will not apply, because everyone should know customary land is inalienable, and any dealing will be ruled as fraud which renders the title impeachable. Indeed, the Office of the Attorney General assures the public that the Act "does not apply indefeasibility of title to customary land". ${ }^{169}$

However, after registration the situation of whether adjudicated customary land remains customary land or becomes freehold land is far from clear. Section 12(1) of the LTA 1981 specifies that a memorial, which shows that the land concerned in the judgment is customary land, should be entered in the Land Register. ${ }^{170}$ However, as has been argued above, the LTRA 2008 registration of customary land could be different from the LTA 1981 registration. The LTRA 2008 does not contain a section like s 12(1) of the LTA 1981, and thus does not specify whether adjudicated customary land should be registered as customary land or freehold land. As a general principle, the Torrens "registration of customary land as customary land would appear to be a contradiction in terms, as the essence of custom (and so of customary tenure) is that it should be unwritten". ${ }^{171}$ Therefore, without express language, it seems that the inclusion of land in the Land Register indicates the land is freehold. Potentially the Land Registrar can and will take a cautious approach and enter a memorial showing adjudicated customary land is customary land. However, under Torrens "[n]othing can be registered the registration of which is not expressly authorised by the statute". ${ }^{172}$ Since the LTRA 2008 does not specify adjudicated customary land should be registered as customary land, the noting of it as customary land will not have legal effect. Rather, it serves as a caution to purchasers. Section 33(1)(c) of the LTRA 2008 specifies that a purchaser from the registered proprietor will not be affected by notice. Thus a purchaser can ignore the caution without

169 Office of the Attorney General, above n 38.

170 Note that the definitions of Land Register are different in the LTRA 2008 and the LTA 1981, which refers to the Samoa Land Registration Order 1920.

171 Simpson, above n 40, at 233.

172 Fels v Knowles (1906) 26 NZLR 604, 620 Edwards J, quoted in NZLC LTA 1952 Review, above n 168, at 19. 
rendering the title impeachable. This interpretation is supported by s 9(3). Section 9(3) provides that adjudicated customary land is to be registered in the ordinary folio, together with freehold land, public land and lease hold interests. The Torrens indefeasibility applies to ordinary folios, ${ }^{173}$ as opposed to qualified folios to which indefeasibility does not apply. ${ }^{174}$

In New Zealand, all the customary land investigated by the Maori Land Court has been converted to freehold land - earlier by Court grant and later by registration of title. ${ }^{175}$ As has been pointed out, determination of ownership by the Maori Land Court does not convert customary land; the registration of title does. ${ }^{176}$ Indeed, title indicates individual ownership in those on the title, no matter how many owners there might be for the same piece of land. Arguably Samoan adjudicated customary land will be converted to freehold land over time without a change in the substantive law.

This possibility of converting customary land into freehold land applies to all adjudicated customary land, but the category of pulefaamau presents the most risk. Pulefaamau means "the ownership of any customary land or the control of any Samoan name or title either by a person in his sole right or on behalf of any Samoan title, family, village or district". 177 Section 14 of the LTA 1981 provides for confirmation of pulefaamau, which is one of the four main categories of disputes in the Land and Titles Court. ${ }^{178}$ Pulefaamau is said to be "similar to the concept of individual ownership" as the owner has exclusive occupation and usage of land, and the ownership is recognised as that person's individual right, which can be inherited by the heirs of the registered title holder. ${ }^{179}$ With the registration of title, the customary land under the pulefaamau will complete its last step of individualisation, and freely enter into the open market.

This is possible even in light of the language of the Constitution. Article 102 of the Constitution forbids the "alienation or disposition" of customary land. Alienation and disposition are not defined in any of the Constitution, Alienation of Customary Land 1965, Alienation of Freehold Land 1972, the LTA 1981 or the LTRA 2008. The definition of alienate is "transfer ownership of (property rights) to another". ${ }^{180}$ The definitions of alienation in the Maori Land Act 1993 of New Zealand and

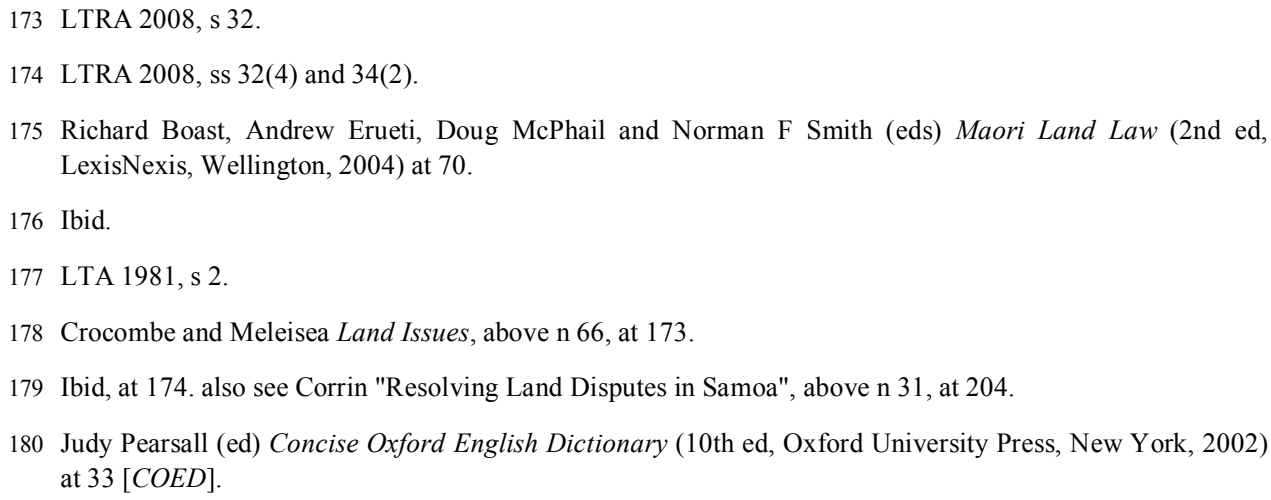


the Niue Amendment Act 1968 may provide an analogy to the Samoan situation; both point to disposition of property rights to another person. ${ }^{181}$ The definition of disposition is "the action of distributing or transferring property or money to someone". ${ }^{182}$ Therefore, arguably conversion of the customary land into freehold is not alienation, if the ownership of land does not change hands and rights in customary land are not limited through such conversion. If conversion is not alienation, it is not against the language of the Constitution. As soon as the land is registered as freehold land, article 102 does not apply anymore and the land is alienable. This is clearly against the spirit of the Constitution to protect customary land tenure. In this sense, by opening a door to privatisation of customary land, the LTRA 2008 is repugnant to the Constitution.

\section{Under whose name the land should be registered}

It is not clear under whose name the land would be registered. As noted above, the LTA 1981 registration only requires record of judgments and entrance of a memorial showing the land concerned is customary land. The LTRA 2008 does not provide a workable registration mechanism for adjudicated customary land.

There are three possible models: under the matai's name, under the aiga's names to be held in joint tenancy ${ }^{183}$ or tenant in common, or under a corporation which is formed by the aiga. The registration of group ownership either by way of multiple ownership or corporation ownership is not without problems. Since any heir of the aiga is the potential owner of the family land, the group of owners is in constant change. The certainty of ownership guaranteed by the registration is by its nature in conflict with the flexibility of customary land tenure. More seriously it may cause more litigation and deprive other members of the group of the right to exercise the option of coming back to the family land, since the owners on the registration might want to exclude any new claimants to the land, and use the indefeasibility as a shield to new claims. The registration of multiple ownership might also cause the fragmentation of land holding, as Simpson observes ${ }^{184}$ and as Maori freehold land holding demonstrates. Furthermore, some fear that with the aiga having secure tenure over their land, the incentive to serve the matai disappears, and the cultural and social foundation of Samoa society will break down over time.

However, more probably Samoa will adopt the first model of registration under the matai's name. This is because under the customary law, the matai is the title holder. Furthermore, s 23(1) preserves the Registrar's right to register trust instruments where adjudicated customary land is

181 Maori Land Act 1993, s 4; Niue Amendment Act (No 2) 1968, s 2.

182 COED, above n 180 , at 413.

183 Under s 24 of the LTRA 2008 multiple ownership is deemed to be joint tenancy.

184 See Simpson, above n 40, at 242. 
concerned, which indicates the registration will be under the matai's name holding the title on trust for the aiga. This is also problematic as will be demonstrated in the following section.

\section{B Registration of Trust and the Principles of Torrens}

It is suggested that the registration of title "succeeds or fails according to the degree with which the local law and local administration accord with three fundamental principles": 185 the mirror principle, the curtain principle, and the insurance principle. The LTRA 2008 confirms that it is lawful for the Registrar to register a trust instrument in respect of any customary land registered under the LTA 1981, but registration of trust with respect to customary land runs against the three principles of Torrens.

\section{The mirror principle}

The mirror principle "involves the proposition that the register of title is a mirror which reflects accurately and completely and beyond all argument the current facts that are material to title". ${ }^{186}$

However, the registration of adjudicated customary land by way of noting trust cannot mirror the accurate and complete situation of customary land. As has been argued earlier in this article, although a matai is often referred to as the trustee of the family land, and the aiga the beneficial owners, neither the matai's pule over land nor the aiga's tautua interest equates to ownership as understood by western property concepts. Two of the basic elements of trust are certainty of beneficiary and certainty of trust property. However, the beneficiaries are often uncertain since the membership of the so-called beneficial owners of the customary land is ever changing. Some descendants leave the land, stop rendering service and thus lose rights to the land, while other ones come back to work on the land and gain rights to the land. It is arguable that the aiga as a whole can be registered as the beneficial owner, and as long as the group can be ascertained at any specific time, the trust is valid. However, the membership of the group is often in doubt, or at least there is a lot of variation amongst those who wish to avail themselves of their rights as members of the aiga. More importantly, the registration of the aiga as the beneficial owner cannot reflect the fact that they occupy different plots of land, that they have different rights to the land, and that their rights are changeable under different circumstances.

One clear example is the situation when an aiga member clears bush land. Where a person clears the forest land and cultivates it, the Court may define the exact faletame (lineage which descended from the original bush-feller and cultivator) that should own and use disputed land. ${ }^{187}$ Thus, the land is almost exclusively occupied and used by the person who clears it, and the right to

\footnotetext{
185 Ibid, at 22.

186 Ibid.

187 Crocombe and Meleisea Land Issues, above n 66, at 173 and 179.
} 
usage and occupation can be inherited by that person's descendants. ${ }^{188}$ However, the pule over the newly-cleared land is vested in the matai. ${ }^{189}$ This is a situation that some argue is land tenure individualisation, ${ }^{190}$ while others recognise it as one that "still fall[s] within the requirements prescribed by custom and usage". ${ }^{191}$ The registration of this type of land is unable to mirror the material facts of customary land rights. On the one hand, the registration of the aiga as the beneficial owner will deprive the bush-feller of his and his heirs' exclusive right to usage and occupation. On the other hand, the registration of the bush-feller or his descendants as beneficial owner cannot reflect the fact that their right depends on their continuing service to the matai.

It was recognised that "no register could ever contain the full complexity of traditional [rights] to land in any Pacific society". ${ }^{192}$ Although a good attempt, the registration of trust with regard customary land does not accord with the mirror principle.

\section{The curtain principle and the compensation principle}

The curtain principle provides that "the register is the sole source of information for proposing purchasers who need not and, indeed, must not concern themselves with trusts and equities which lie behind the curtain". ${ }^{193}$ Only in very exceptional circumstances will trust be registered. ${ }^{194}$ In Samoa, where the vast majority of land is customary land, and a large amount of customary land has been subject to Land and Titles Court decisions, the noting of trust in the Register will become the norm instead of exception, if all adjudicated customary lands are registered and trust properly noted. However, it is not argued here that the trust relationship should not be noted. The point is that the adjudicated customary land should not be included in an Act where indefeasibility of title is the mandate.

The Torrens system as used in other countries, such as Australia and New Zealand, strictly excludes registration of trust. There is no precedent to suggest what the effect of the registered trust will be. Looking within the LTRA 2008, there is no provision on the effect of registering trust instruments under the new regime. Sections 32 and 33 provide that the estate of the registered proprietor is paramount, and that a purchaser from registered proprietor will not be affected by notice. These two sections are in effect similar to sections 62 and 182 of the Land Transfer Act 1952

188 Ibid, at 142 .

189 Marsack, above n 70

190 See O'Meara above n 74, generally.

191 Crocombe Land Tenure, above n 66, at 122.

192 Acquaye and Crocombe Land Tenure and Rural Productivity, above n 18, at 39.

193 Simpson, above n 40, at 22.

194 For example, s 129 of the Land Transfer Act 1952 (NZ) provides registration of trusts of public reserves and other public lands. 
(NZ) respectively. The provisions expressly exclude lands comprised in a qualified folio, but do not address the issue of registered trust. Instead, section 33 specifies that knowledge that a "trust or unregistered interest is in existence" is not fraud, which is an exception to indefeasibility. The provision treats trust and unregistered interest as two different types of interests, ${ }^{195}$ which arguably means trust includes registered trust, as opposed to trust as a type of unregistered interest. Thus, purchasing the land with the knowledge of a registered trust may still not constitute fraud, as is the case in purchasing the land with the knowledge of unregistered interest. This may be so even where there is some dishonesty involved. In Beale v Tihema Te Hau, ${ }^{196}$ although the plaintiff was unlikely to be blameless, in that she knew that the native owners had never been out of possession, ${ }^{197}$ the then Supreme Court of New Zealand held that her title was indefeasible, ${ }^{198}$ and the whole village was removed from their land.

Therefore, the practical effect of sections 32 and 33 is that the alienation of customary land will breach the substantive law and thus be illegal, but the bona fide purchaser's title will still be unimpeachable. If the aiga lose their land, they would not be able to get it back, and their only possibility of redress would be to get government compensation.

However, customary land is valuable to the society in many aspects, and is not measurable by money. ${ }^{199}$ Furthermore, although the LTRA 2008 adheres to the compensation principle, the adjudicated customary land will not be covered in most situations. Section 79(2)(e) specifies that "the loss or damage [arising] from the breach by a registered proprietor of any trust" cannot be compensated by the government. Section 79(2)(e) uses the term "any trust", which includes the trust interest in the adjudicated customary land. Therefore, even if the Registrar registers the trust, the beneficial owners will not be compensated if they lose their land through the operation of the Act. Since the only protection of the aiga's interest is through the registration of trust, the rejection of compensation from breach of trust deprives them of their rights altogether. Thus the aiga may be left without redress.

The best hope for the aiga is that the trust is made an overriding interest on the legal ownership; the Act does not provide for that. New Zealand's Land Transfer Act 1952 specifies that registered trust has "the effect of a perpetual caveat to restrain any dealing with the lands affected". ${ }^{200}$ The LTRA 2008 lacks such provision. The Registrar's power to deposit a caveat on his own motion does

\author{
195 The Land Transfer Act 1952 (NZ) uses the same language. \\ 196 Beale v Tihema Te Hau (1905) 24 NZLR 883 (SC) Ewards J [Beale]. \\ 197 See Boast "The Implications of Indefeasibility for Maori Land", above n 168, at 106-107. \\ 198 Beale, above n 196 \\ 199 Customary Land Tenure Review, above n 19, at 16.
}

200 Land Transfer Act 1952 (NZ), s 129(5). 
not include caveat on registered trust. ${ }^{201}$ Theoretically, the beneficial owners can apply for a caveat under s 51. A caveat for the protection of any trust is excluded from the provision on lapse of caveat. ${ }^{202}$ Arguably this means that the caveat will not lapse. However, since the caveat is by application, the protection on beneficial owners is not as complete and effective as an automatic Registrar's caveat. The caveat can also be removed on application, which may cause more litigation on removal of caveat.

In the end, it should be noted that the registration of trust is not compulsory. ${ }^{203}$ This again increases the opportunity for the beneficial owners to lose their land.

Another provision that pushes customary land owners further along the way of losing their land is s 35 of the Act. According to s 35(2) of the Act, even if the vendor or mortgagor of the land has been registered as proprietor through fraud or error, or by means of a void or voidable instrument, the bona fide purchaser or mortgagee still has unimpeachable title. This means that even if the above probable detriments to customary land owners are well-safeguard against, a further transfer will deprive them of their land. Section 35(2) is identical to s 183 of the Land Transfer Act 1952 in New Zealand. Even under a "particularly complete"204 and well established Torrens system such as the one in New Zealand, "the development of the doctrine of indefeasibility of title allowed [the] statutory protection mechanisms to be subverted by the simple device of selling the property to a third party". ${ }^{205}$ For example, in Frazer $v$ Walker, ${ }^{206}$ one of the registered proprietors forged documents and fraudulently granted a mortgage to the mortgagee. Walker was the bona fide purchaser. The Privy Council held that not only that Walker's title was unimpeachable, but also that Frazer would not have valid claim against the mortgagee. ${ }^{207}$ The Australian leading case Breskvar v Wall has similar effect. ${ }^{208}$

The LTRA 2008 does not have a coherent protection mechanism to match its substantive law; the application of indefeasibility arguably will destroy the customary land owner's interests more quickly than it has in New Zealand.

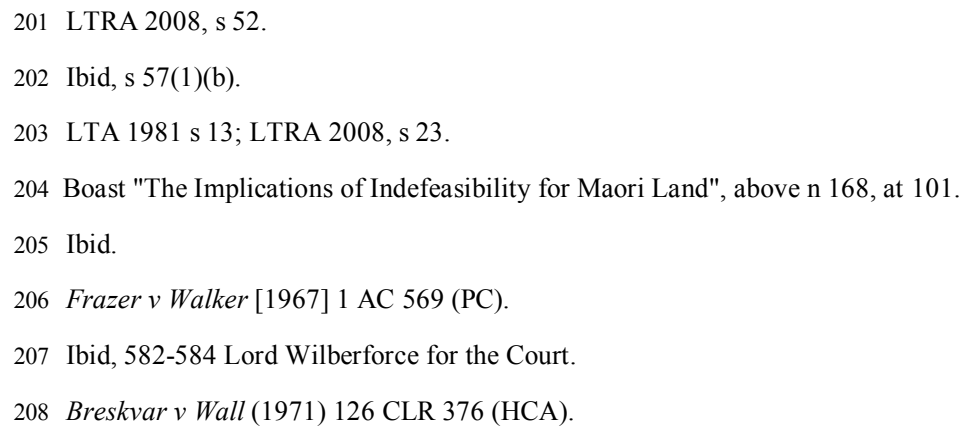




\section{The Effects of Registration: in Summary}

The LTRA 2008 is ambiguous in many aspects as to the registration of adjudicated customary land. It takes some provisions directly from the LRA 1992/1993, which provides a different registration system; and borrows provisions from other countries that apply the Torrens system, which may not suit Samoa's particular circumstances. The patch-work manner of drafting causes confusion and opens the registration of adjudicated customary land to different interpretations. One of the interpretations is that the LTRA 2008 creates a parallel registration system to the LTA 1981 registration, and allows the Torrens system to apply to adjudicated customary land.

Simpson points out that registration of title is not a land reform, that it is a device which facilitates substantive law, and that it is a means to an end. ${ }^{209}$ This is true in that a government seeking to increase land productivity cannot rely solely on the change of registration itself to bring about the land reform. However, "the cardinal principle of [the Torrens system] is that the register is everything". ${ }^{210}$ As the indefeasibility becomes absolute, it is commonly recognised that Torrens is "title by registration", ${ }^{211}$ which recognises the power of registration to confer title. As Andrew Tipping put it in his extra-judicial writing, the Torrens system "is not so much a system of registering a pre-existing title; rather it is a system of creating legal title through the process of registration". ${ }^{212}$ The LTRA 2008 adopts this approach; its overarching purpose is "the establishment of ownership of interests in land by registration". ${ }^{213}$ The Torrens system has changed property law relating to land very significantly in a number of key respects - the obliteration of the nemo dat rule is but one of them. ${ }^{214}$ Indeed, although some commentators believe that customary land can be registered as customary land, they admit that such registration "is usually accompanied by material changes in some aspects of customary land tenure". ${ }^{215}$

This is also the possible effect of the LTRA 2008 in Samoa. It is open to interpretation that adjudicated customary land can be registered as freehold land, which is alienable. The registration of trust instrument with respect to adjudicated customary land cannot protect the aiga's interest. First, it does not reflect the complex state of the customary land rights. Secondly, it is not compulsory. If the Registrar does not register it, the omission is not unlawful. The Registrar might omit it, or the

209 Simpson, above $\mathrm{n} 40$, at 3.

210 Fels v Knowles, above n 172, at 602 Edwards J.

211 See, for example, G W Hinde "Foreword" to Torrens in the Twenty-first Century, above n 128, v, at v.

212 Andrew Tipping "Commentary on Sir Anthony Mason's Address" in Torrens in the Twenty-first Century, above n 128 , at 21

213 LTRA 2008, preamble.

214 Boast in "The Implications of Indefeasibility for Maori Land", above n 168, at 109.

215 Acquaye and Crocombe Land Tenure and Rural Productivity, above n 18, at 5. 
beneficial owners might not come up with a trust instrument. Thirdly, the law omits to provide protection for the registered trust, rather it treats any trust the same as an unregistered interest. Fourthly, even if the customary land owners succeed in protecting their interests at this stage, a further transfer will effectively deprive them of their rights by the operation of s 35 .

The registration of adjudicated customary land may reduce disputes on customary land because pule over the adjudicated land is certain and cannot be challenged. However, this can be achieved simply by the law giving such effect to the judgment. Furthermore, registration of customary land may also increase instead of reduce disputes. One of the merits of the Torrens registration system is that it effects certainty of title. However, the simplified approach of "registered proprietor title paramount" cannot capture the comprehensive operation of customary land tenure. The crystallisation of flexible customary land rights could cause more disputes, especially within the clan.

Although Torrens "has so many advantages over other systems of land registration, including even the best deeds system", 216 it has also caused major injustice to the indigenous people who practise customary land tenure. The application of Torrens indefeasibility in Beale v Tihema Te Hau caused "the entire community [to lose] its land". ${ }^{217}$ Samoa should be wary of this consequence.

\section{The Inappropriateness of Applying Torrens to Customary Land}

Even if the LTRA 2008 is capable of a different interpretation and registration of adjudicated customary land will not have the detrimental effect as analysed above, the meaningfulness of the registration is in doubt. The most important merit of the Torrens system is that it "makes dealing simple, cheap and certain, and thus promotes 'mobility' in land transfer". ${ }^{218}$ Therefore, it was recognised that the main advantages of the Torrens system are in situations "where land is being freely bought and sold". ${ }^{219}$ On the one hand, the facilitation of cheap and speedy transactions weakens the protection of inalienability of customary land. On the other hand, the inalienability of customary land renders the application of Torrens to customary land meaningless. They are incompatible due to their respective characteristics.

Simpson's argument that the Torrens system is "merely the instrument by which a policy can be effected"220 was right and has gained support. ${ }^{221}$ However, there is no substantive law reform in

\footnotetext{
216 Simpson, above n 40, at 188 .

217 Boast "The Implications of Indefeasibility for Maori Land", above n 168, at 109.

218 Simpson, above n 40, at 236.

219 R G Crocombe Improving Land Tenure (South Pacific Commission Technical Paper No 159, Noumea, 1968) at 4.

220 Simpson, above $\mathrm{n} 40$, at 169 .

221 Acquaye and Crocombe Land Tenure and Rural Productivity, above n 18, at ch 1.
} 
Samoa. The Samoan government denies the intent to change the present law concerning customary land tenure. It asserts that the main purpose of the LTRA 2008 is to change the registration system, ${ }^{222}$ which was "part of the on-going Government reforms to assist landowners strengthen the administration of their land and improve the security of their titles". ${ }^{223}$ The main purpose of improving security of title is to enable land owners to obtain loans for development by mortgaging their land. ${ }^{224}$ However, the discussion about securing loans simply ignores the fact that customary land cannot be mortgaged in Samoa, unless the Constitution is amended.

\section{E A Better Recording or Registration System}

Customary land, which is inalienable and subject to complex rules, is incompatible with the Torrens system, which is simple and facilitates speedy transactions. Customary land, at least in Samoa's case, should not be registered, but should be recorded. The LTRA 2008 includes a provision for recording customary land, but it is not clear how it would operate.

Section 5(1)(1) of the LTRA 2008 stipulates that:

[T] he Registrar may maintain a record of customary land showing location, description, detail of persons having administrative or trustee responsibilities in respect of the land and such other details as the Registrar sees fit to include.

This paragraph confers one of the Registrar's powers which are "in addition to any other powers conferred" on the Registrar by the LTRA 2008. ${ }^{225}$ There is no provision on the effect of the record. The record is "separate from and in addition to" the registration of adjudicated customary land, ${ }^{226}$ which implies the record extends to any customary land. There is no definition of "record" or provision on whether the record is part of the Register, or whether such records are exempt from the indefeasibility effect. Since s 9 "Inclusion of land" does not include general customary land, it is possible that the record is not part of the Register, but just an ordinary recording system. If this is the case, the LTRA 2008 should specify that the recording does not confer indefeasibility of title, but purports to build up data on customary land. Furthermore, the Act should make the record a systematic work instead of a discretionary power that the Registrar can choose whether to exercise or not.

222 Office of Attorney General, above n 38.

223 Ieti Taulealo (Land Register) "Land Title Registration Act 2008" (22 February 2009) Samoa Observer $<$ www.samoaobserver.ws $>$.

224 See the discussion in Customary Land Tenure Review, above n 19.

225 LTRA 2008, s 5(1).

226 LTRA 2008, s 5(6). 
This way, the registration is a collection of valuable data for future reference, but leaves to the Land and Titles Court the exclusive authority in determining the rights regarding customary land. There will always be disputes on customary land rights, but so long as the Land and Titles Court has a clear principle and ample information, disputes can be solved more quickly and reduced over time.

If customary land is to be registered, the law should take a holistic approach, and coordinate the different statutes. As indicated earlier in this article, some provisions in the LTRA 2008 are directly taken from the LRA 1992/1993 which in turn were inherited from the Land Registration Orders 1920 (NZ). Some provisions are copied from other Torrens models. They do not coordinate with the LTA 1981, and do not coordinate within the Act itself. The inconsistent and ambiguous provisions open the LTRA 2008 to different interpretations. Arguably registration could convert customary land into freehold land, and the indefeasibility applies to registered customary land.

The government has stated that the LTRA 2008 does not change the current law on customary land and indefeasibility does not apply to customary land. If this is the case, the statute should unequivocally require customary land to be registered as customary land, and state that indefeasibility does not apply to registered customary land. Furthermore, the best way of registration is to go back to the recommendations of the Review Committee, and register pule and tuatau interests instead of ownership and trust.

\section{REGISTRATION OF TITLE AND COMPULSORY TAKING OF LAND}

The Head of State may take customary land or freehold land for any public purpose, ${ }^{227}$ and convert the taken land into public land.

There have been complaints against taking of land by the Government, the salient points being the compensation issue and the on-sale of land by the Government. Generally the compensation for customary land is lower than for freehold land, partly because freehold lands are scarce, and partly because customary land has no market value (which is the benchmark of compensation) since it cannot be sold on the market. Moreover, the Taking of Land Act allows the Government to sell or lease public land that is not needed. ${ }^{228}$ The sale is by private contract, and the price is fixed by "a competent valuer, or by public auction, or by public tender". ${ }^{229}$ There have been claims that the Government uses the Taking of Land Act to privatise customary land, ${ }^{230}$ because the land sold by the government becomes freehold land, whether it is on-sold to the original owner or other people.

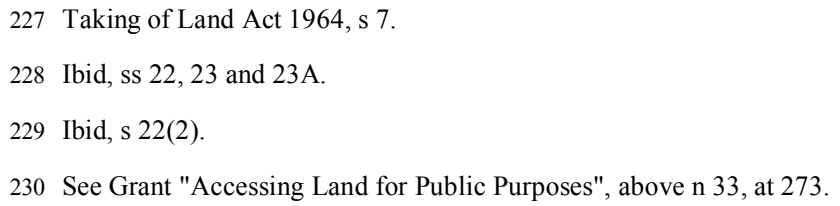


With the commencement of the LTRA 2008, the indefeasibility of title will assist Government's operation in this regard. No matter whether the instrument to take land is valid or void, the purchaser of the public land gains unimpeachable title. The New Zealand case Boyd v Mayor of Wellington $^{231}$ is a good example of the injustice the Torrens system can do to the owner of the taken land. In that case, Wellington City Corporation took the plaintiff's land by a void instrument and was registered as the proprietor. The Court held by majority that the defendant's title was valid. ${ }^{232}$

More seriously, because the land taken ceases to be customary land, the combined effect of the Taking of Land Act 1964 and the LTRA 2008 opens up the opportunity to bypass the Constitution and to privatise customary land. This could happen in a large scale since the Government's power to take land under the Taking of Land Act 1964 is large. Public purposes range widely from defence and telecommunication to provision of sites for townships and burial of the dead, and "all lawful purposes and function of the Government of Samoa". ${ }^{233}$ Furthermore, the Head of State may declare "any purpose" to be a public purpose. ${ }^{234}$ Written notice will be given for taking land, but the time allowed for the land owner to object to the taking of land is within 28 days of the notice. ${ }^{235} \mathrm{In}$ reality, lands are often taken without notification. ${ }^{236}$ Anyway, objections can be disregarded by the Minister or the Head of State. ${ }^{237}$ The operation will be like New Zealand's conversion of customary land into freehold land in the early settlement days, through the Crown's pre-emptive right to purchase lands from Maori, and sell them to settlers. The consequences have been devastating in New Zealand, causing a century's grievance to the native people and disturbance to the development of the nation. This is a consequence that the Samoans fear, and arguably is a more crucial issue than the piecemeal registration of adjudicated customary land.

As indicated earlier in this article, the Land and Titles Amendment Act 2008 provides that "any land conveyed by Government or any public body by way of deed which provides that the land shall be held in accordance with the customs and usages of the Samoan people" is deemed to be customary land. The Amendment Act was passed shortly before the LTRA 2008, ${ }^{238}$ and might have been part of the Infrastructure Asset Management programme. Possibly this amendment is to address the issue of sale back of customary land taken, and implies that land sold by the government

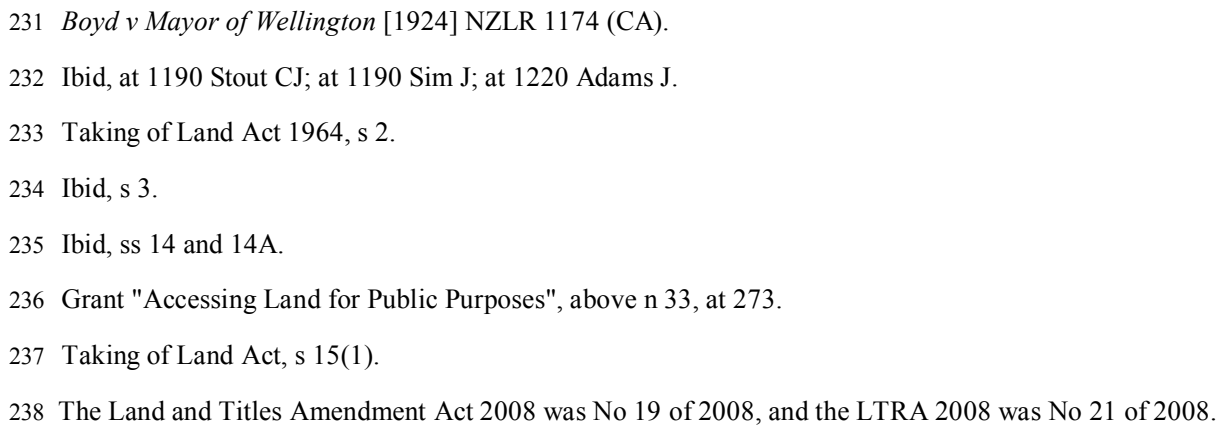


to the original owners remains customary land. However, the provision is vague, and the government still has power to manipulate the conversion of customary land into freehold land through the Taking of Land Act 1964.

\section{CONCLUSION}

While promoting registration of customary land, Simpson admits that there are places "where registration of title will serve no useful purpose and to introduce it would only be an expensive exercise in sheer futility." ${ }^{239}$ Samoa seems to be such an example, and has introduced the Torrens system simply for the sake of introducing it, without appreciating the nature and effect of a Torrensstyle system and the constitutional reality of the land tenure. In the face of the community's hostility towards the application of Torrens system to customary land, the Government drafted the LTRA 2008 without a holistic approach, leaving inconsistencies and loopholes in the Act as well as between the Act and other substantive law statutes.

The two major areas of concern are the registration of adjudicated customary land and the combined effect of the LTRA 2008 and the Taking of Land Act 1964.

In allowing registration of adjudicated customary land, the LTRA 2008 does not specify whether adjudicated customary land should be registered as customary land or freehold land. This is an omission with significant effect. The interpretation of the law suggests that customary land could be registered as freehold land, which can then be bought and sold. This is against the spirit of the Constitution. Furthermore, the LTRA 2008 states that adjudicated customary land is contained in the ordinary folios, and thus is affected by indefeasibility. The voluntary registration of trust cannot reflect the complexity of customary land rights, and the LTRA 2008 does not give sufficient protection to registered trusts. If the government intends to protect customary land tenure as it claims, it is meaningless to register customary land. The Torrens system will facilitate transactions but this is not consistent with customary inalienable land. This article recommends systematic recording to replace sporadic registration. It suggests that otherwise the statute should expressly specify that customary land should be registered as customary land, and that indefeasibility would not apply. It also suggests registration of pule over land and tautua interests instead of title to land and trust.

The Taking of Land Act 1964 gives the government wide power to take land for public purposes, which can be any purpose the head of State declares. In reality, the procedures in taking land are often not complied with, and the government can sell land taken as freehold land. The operation of Torrens system in this regard could permanently deprive customary land owners of their land. The Land and Titles Amendment Act 2008 might be an attempt to keep land re-sold by the government as customary land. However, the Amendment Act is very general, and the attempt

239 Simpson, above n 40, at 189. 
can only be implied. The government still enjoys the power to take land and convert it into freehold land.

In conclusion, the application of the Torrens system to customary land is detrimental and unnecessary, the drafting of the LTRA 2008 is confusing, and the effect of the registration of title could be more far reaching than has been expected. 
